\title{
The Croatian-Japanese SATREPS Joint Research Project on Landslides (IPL-161)
}

\author{
Željko Arbanas, Snježana Mihalić Arbanas, Kyoji Sassa, Hideaki Marui, \\ Hiroshi Fukuoka, Martin Krkač, Martina Vivoda Prodan, Sanja Bernat \\ Gazibara, and Petra Đomlija
}

\begin{abstract}
The Croatian-Japanese joint research Science and Technology Research Partnership for Sustainable Development (SATREPS) project 'Risk Identification and Land-Use Planning for Disaster Mitigation of Landslides and Floods in Croatia' was performed from 2009 to 2014. Key objectives of the project were landslides and floods hazard analysis and the development of guidelines for use in urban planning. This project is also designated as on-going IPL project 161 . The aims of the working groups dealing with landslides were to establish a methodology of comprehensive real time monitoring at two most important landslides in Croatia based on the results of previous investigations and new in situ and laboratory testing and behavior analysis; laboratory soil testing and numerical modelling of static and dynamic landslide behavior; development of landslide inventories using direct sensing and remote sensing techniques followed by the development of methodologies of landslide hazard analysis and zonation in three pilot areas in Croatia. In this paper we will present the most important achievements of working groups related to landslide studies at the project pilot areas: two in Primorsko-Goranska County (the Rječina River Basin and the Dubračina River Basin) and one in the City of Zagreb (a hilly area of Medvednica Mt.). The identification and mapping of existing landslides in the hilly area of Medvednica Mt., Dubračina River Basin and Rječina River Basin so as establishment and results of the monitoring systems installed on the Grohovo Landslide and the Kostanjek Landslide will be described.
\end{abstract}

\section{Keywords}

Landslide • Monitoring • Early warning system • Hazard zonation • Risk mitigation

Ž. Arbanas $(\bowtie) \cdot$ M. Vivoda Prodan $\cdot$ P. Đomlija

Faculty of Civil Engineering, University of Rijeka, Radmile

Matejčić 3, 51000 Rijeka, Croatia

e-mail: zeljko.arbanas@gradri.uniri.hr

M. Vivoda Prodan

e-mail: martina.vivoda@gradri.uniri.hr

P. Đomlija

e-mail: petra.domlija@gradri.uniri.hr

S. Mihalić Arbanas · M. Krkač · S. Bernat Gazibara Faculty of Mining, Geology and Petroleum Engineering, University of Zagreb, Pierottijeva 6, 10000 Zagreb, Croatia e-mail: snjezana.mihalic@rgn.hr

M. Krkač

e-mail: martin.krkac@rgn.hr
S. Bernat Gazibara e-mail: sanja.bernat@rgn.hr

K. Sassa

International Consortium on Landslides, Tanaka Asukai-Cho 138-1, Kyoto, 606-8226, Japan

e-mail: sassa@iclhq.org

H. Marui · H. Fukuoka

Niigata University, Research Institute for Natural Hazards and Disaster Recovery, 8050Igarashi, Nino-Cho, Niigata 950-2181, Japan

e-mail: maruihi@cc.niigata-u.ac.jp

H. Fukuoka

e-mail: fukuoka@cc.niigata-u.ac.jp 


\section{Introduction}

The Croatian-Japanese Joint Research Project entitled "Risk Identification and Land-Use Planning for Disaster Mitigation of Landslides and Floods in Croatia" was launched in 2008 when it was selected as one of the initial projects of the Science and Technology Research Partnership for Sustainable Development (SATREPS) programme. The project was approved as an ongoing IPL project (IPL-161) by the IPL Global Promotion Committee in 2009 (Han et al. 2017). SATREPS is a Japanese government program that promotes international joint research. The program is structured as a collaboration between the Japan Science and Technology Agency (JST), which provides competitive research funds for science and technology projects, and the Japan International Cooperation Agency (JICA). The SATREPS program enables joint research of Japanese and Croatian researchers by financing travel of the project members between project institutions and donating equipment for implementation of project activities. The main Japanese partner institutions in the Project were Research Institute for Natural Hazards and Disaster Recovery at Niigata University, the International Consortium on Landslides (ICL), the Disaster Prevention Research Institute of Kyoto University (DPRI). Three Croatian universities, the University of Rijeka (Faculty of Civil Engineering), the University of Zagreb (Faculty of Mining, Geology and Petroleum Engineering and Faculty of Agriculture) and the University of Split (Faculty of Civil Engineering, Architecture and Geodesy) as well as the Croatian Geological Survey were Croatian partner institutions in the project. The five-year project, started in 2009 and completed in 2014, involved about 15 researchers from Japan and included collaborative research conducted in Japan and Croatia to evaluate and mitigate landslide and flood hazards and risks in Croatia. Key objectives of the project were landslides and floods hazard analysis and the development of guidelines for use in urban planning. The project aimed to contribute to sustainable development through appropriate land use in Croatia. The Project researches covered the pilot areas around the cities where the three partner universities are located, namely Zagreb, the capital of Croatia, Rijeka, a port city, and Split, whose historic center is a UNESCO World Heritage Site. Researchers from Japan and Croatia carry out the following investigations and analyses (Mihalić and Arbanas 2013): (1) identification and mapping of landslides, (2) comprehensive monitoring of landslides, (3) continuous monitoring of sediment flows, (4) testing of the physical and mechanical properties of soils and rocks, (5) modeling of landslide dynamics, (6) modeling of flood and debris flow propagation; (7) landslide susceptibility and hazard zonation,
(8) establishment of early warning systems and (9) development of risk mitigation measures through the urban planning system.

The project activities are organized into three working groups: Working Group on Landslides (WG1), Working Group on Flash Floods and Debris Flows (WG2) and Working Group on Landslide Mapping (WG3). The aim of Working Group 1 on Landslides was to establish a methodology of comprehensive real time monitoring at two most important landslides in Croatia: the Grohovo Landslide in Primorsko-Goranska County and the Kostanjek Landslide in the City of Zagreb based on the results of previous investigations and new in situ and laboratory testing and behavior analysis so as a laboratory soil testing and numerical modelling of static and dynamic landslide behavior. The activities of Working Group 3 on Landslide Mapping (WG3) were aimed at the development of landslide inventories using direct sensing and remote sensing techniques followed by the development of methodologies of landslide hazard analysis and zonation in three pilot areas in Croatia: two in Primorsko-Goranska County and one in the City of Zagreb. In this paper we will present the most important achievements of working groups related to landslide studies.

\section{Landslide Monitoring}

One of the most important issues of the Working Group on Landslides (WG1) was establishing the monitoring systems ate two most important active landslides in Croatia: the Grohovo Landslide in Primorsko-Goranska County and the Kostanjek Landslide in the City of Zagreb.

By definition, landslides are characterized by movement. Knowledge of the movement magnitude and velocity distribution along the slope, are the most important data for all landslide analysis (Mihalić Arbanas and Arbanas 2014). Monitoring is required to observe the changing conditions that may lead to total failure of the slope where slope movement is occurring, where safety factors against sliding are low, or where high risk is present from a possible slope failure. Landslide movement monitoring expressed via ground surface displacements and deformation of structures (including the landslide body) related to landslides can be accomplished using different types of monitoring systems and techniques that are classified according to Savvaidis (2003) as follows: satellite and remote sensing techniques, photogrammetric techniques, geodetic or observational techniques, and geotechnical or instrumentation or physical techniques.

Usually, different types of monitoring techniques and instrumentation are used in different combinations and connected in a unique comprehensive landslide monitoring 
system. Following the previously described statements and principles in establishing of landslide monitoring systems, two different concepts of a system were applied to the Grohovo Landslide and Kostanjek Landslide based on previous cognition of landslide characteristics, magnitudes of motion, possibility of equipment installation, visibility of landslide area and availability of powers supply for monitoring equipment.

\section{The Grohovo Landslide Monitoring System}

The Grohovo Landslide, the largest active landslide along the Croatian part of the Adriatic coast, is located on the north-eastern slope of the Rječina Valley out of the City of Rijeka, Croatia. The last complex retrogressive landslide was reactivated in December 1996, after long dormant period and about $1.0 \times 10^{6} \mathrm{~m}^{3}$ moved down the slope and buried the Rječina river-bed. After initial movements, the landslide retrogressively developed up the slope, Fig. 1. Slip surfaces are considered to be on the contact of superficial deposits and flysch bedrock. After removing displaced mass from the landslide foot, further significant movements stopped, and monitoring indicated that only small displacements developed in the upper part of the slope (Benac et al. 2005;
Arbanas et al. 2012b). Comprehensive landslide remediation projects were never conducted, but further movements of the landslide were reduced (Benac et al. 2011).

The Grohovo Landslide monitoring system was designed to consist of geodetic and geotechnical monitoring. Geodetic monitoring will include geodetic surveys with a robotic total station and displacement measurements of GPS points.

The geotechnical monitoring system includes two vertical inclinometers, and four wire extensometers; 13 long- and three short-span extensometers, four pore-pressure gauges, a weather station and a rain gauge. Pore-pressure gauges, inclinometers and vertical extensometers are installed at two locations inside the central part of the landslide body at the same locations as the GPS rovers and prisms. Long-span extensometers (NetLG 501E Osasi, 13 pcs) are installed in a continuous line from the Rječina riverbed to the limestone mega-blocks at the top of the slope, while short-span extensometers (NetLG 501E Osasi, 3 pcs) are installed over the open cracks at the top of the landslide (Arbanas et al. 2014a), Fig. 2. All monitoring equipment is connected in one system with continuous monitoring and export of the data to a central computer unit located at the Faculty of Civil Engineering, University of Rijeka (Arbanas et al. 2012b).

Geodetic monitoring was established with an automatic total station measuring 25 geodetic benchmarks (prisms) and
Fig. 1 Aerial view of the Grohovo landslide reactivated in 1996; the Rječina River channel is situated in the bottom

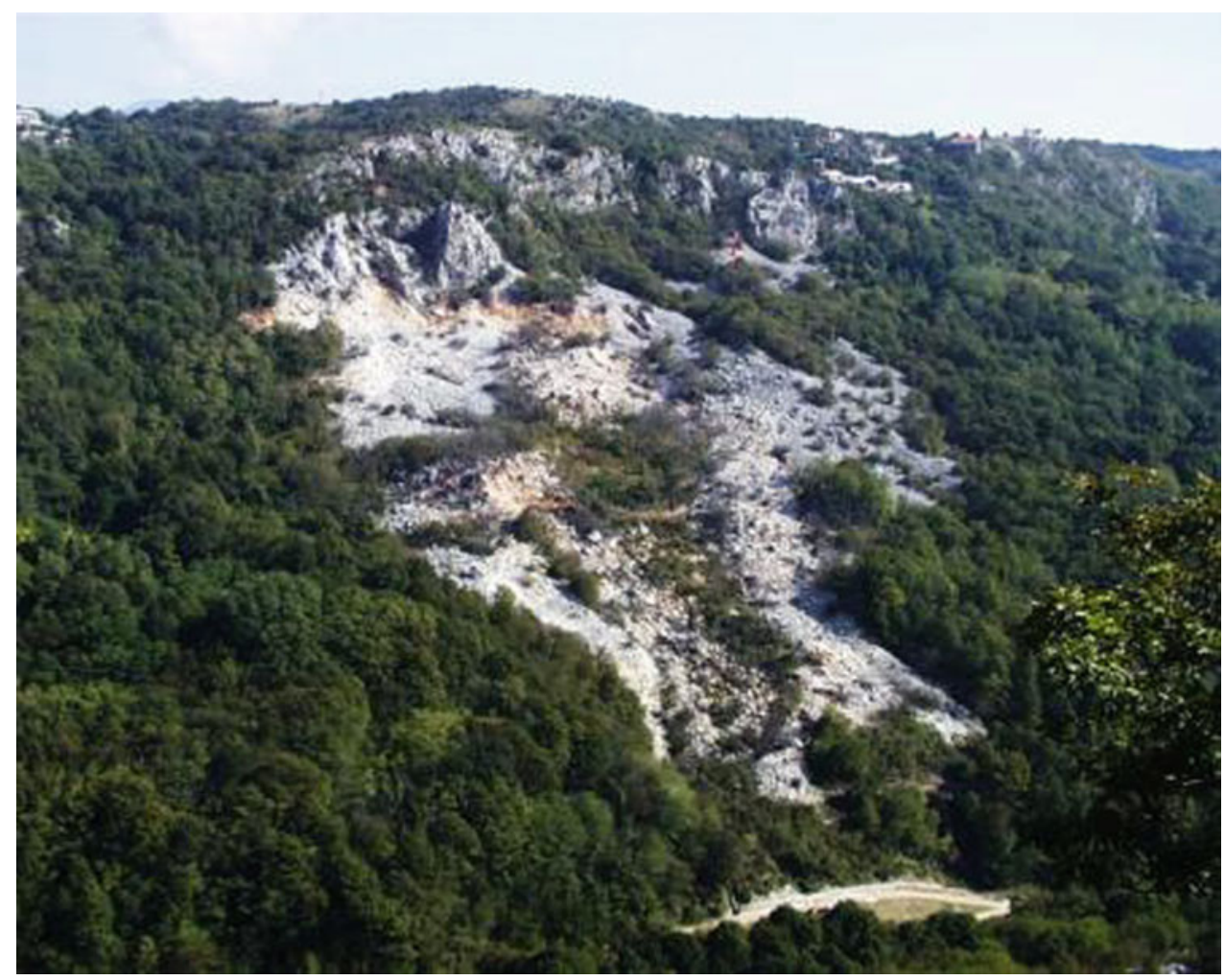


Fig. 2 Installed sensors at the Grohovo Landslide: GPS GPS rover; $I$ prism; $E$ long span extensometer wire,

$P$ extensometer pole; $S S$ short span extensometer; $B$ position of borehole; $I N$ inclinometer casing in borehole; $V E$ vertical extensometer in borehole; $P P$ pore pressure gauge in borehole; $L S$ long span extensometer data logger; $R G$ rain gauge

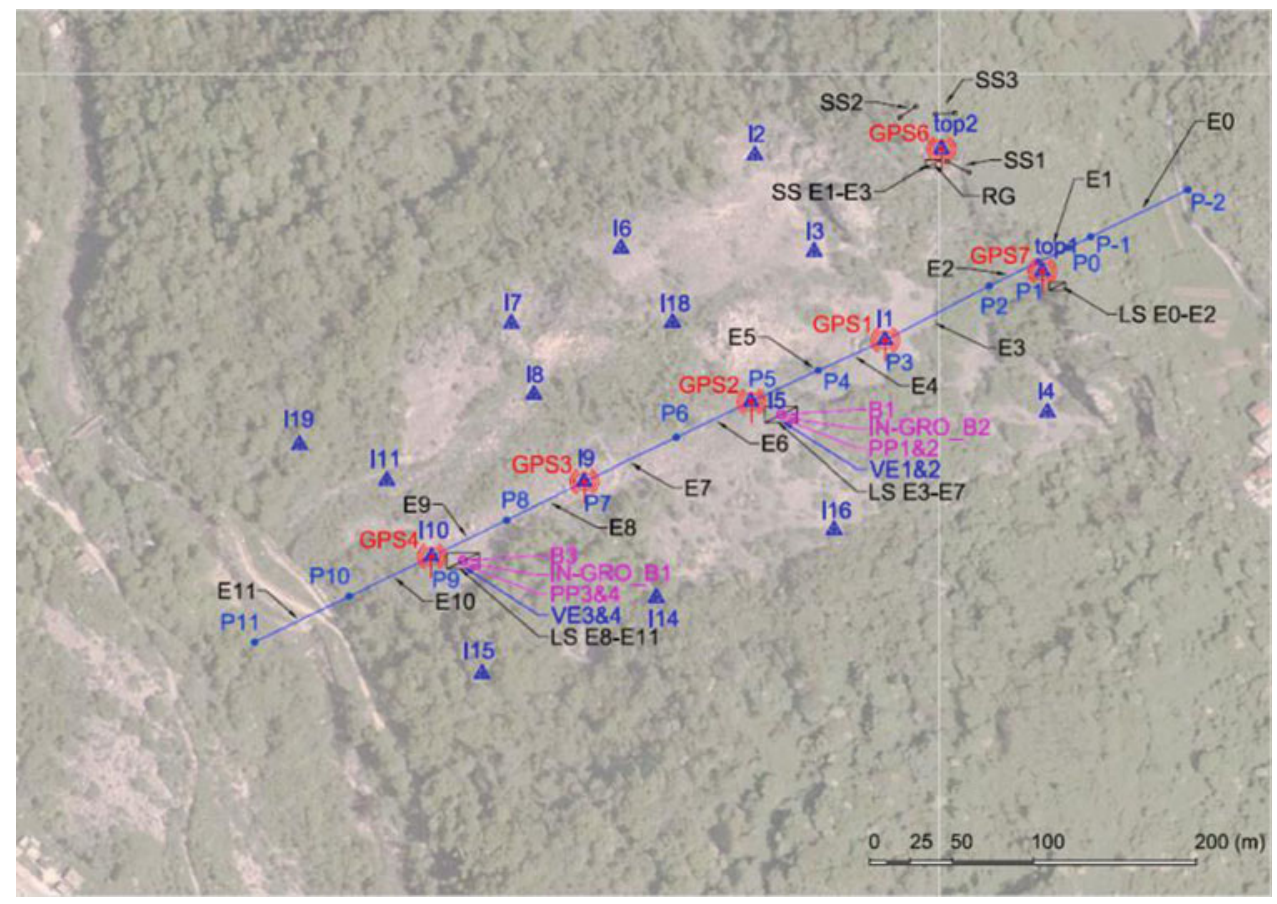

GPS master unit with 9 GPS receivers (rovers). The robotic total station and the GPS master unit are located in a relatively stable area, on the top of the opposite slope. The master unit consists of the robotic total station TM30 Leica, single frequency GPS master unit GMX901 Leica (combined receiver and antenna), meteorological sensor, and web cam. The robotic station measures 25 benchmarks (prisms) located on the landslide body, on the top of the main scarp and, as reference points, around the landslide every $30 \mathrm{~min}$ (Fig. 2.). The GPS network is composed of the GPS master unit which is a reference station for 4 single frequency GPS rovers located in the landslide body, 3 single frequency GPS rovers located on top of the limestone scarp above the landslide, 1 single frequency GPS rover located on dam near landslide, and 1 reference single frequency GPS rover located on Faculty building (Arbanas et al. 2012a, b, 2014a, b). All prisms, for robotic total station measurement, were installed on the same poles with GPS receivers. Data are transmitted by Wi-Fi system from each rover to the GPS master unit connected to industrial master unit PC in which the GNSS Spider software creates measurement data files. The master unit PC is reachable remotely by an UMTS module from the main working station at the University. Instruments in the master unit and GPS rovers are powered from solar panel installations (Arbanas et al. 2012b).

Installation of the monitoring equipment started in May 2011 and establishment of the monitoring was mostly completed at the end of 2011 when the data collection started. All measurement's techniques showed on higher landslide activity in the upper part of the slope while the compression of material and heaving of the GPS rovers and prisms are outlined in the lower part of the landslide body and in the landslide foot.

A relationship between rainfall, ground water level, pore pressures and landslide movement is still very hard to establish because of numerous interruptions of in monitoring system working caused by low energy production of mini solar power plant that supply the main unit (robotic total station, main GPS unit, and site PC unit) during the winter period from end of October to early March when the landslide activity is the most expressed. The second reason is very slow landslide activity $(<5 \mathrm{~mm} /$ year $)$ that requires longer uninterrupted monitoring period.

\section{The Kostanjek Landslide Monitoring System}

The Kostanjek landslide is the largest active landslide in the Republic of Croatia. It is located in the western residential area of the City of Zagreb at the base of the southwestern slope of Medvednica Mt. Since its activation in 1963, this landslide has caused substantial damage to buildings and infrastructure in the residential zone, as well as to factories and commercial buildings. The landslide was mainly caused by anthropogenic factors, including mining and excavation in a marl quarry for cement production at the foot of the hills (Mihalić and Arbanas 2013).

The Kostanjek Landslide is a reactivated, translational type landslide without a clearly defined main scarp or landslide borders. According to Ortolan and Pleško (1992) 
and Ortolan (1996), the Kostanjek Landslide extends over an area of approximately $1.20 \mathrm{~km}^{2}$ with a total volume of displaced mass of $32.6 \times 10^{6} \mathrm{~m}^{3}$. Ortolan and Pleško (1992) correlated movements on the landslide surface with soil layers in the geological profile and deduced three different slip surfaces, the deepest at $90 \mathrm{~m}$ and two subparallel slip surfaces at depths of 65 and $50 \mathrm{~m}$. The positions of the slip surfaces were defined on the basis of unfavorably oriented bedding planes in sediments and sedimentary rocks of Sarmatian and Pannonian age.

Landslide velocities have been changing over the last 50 years, from landslide activation until today, in a range from extremely slow to very slow. According to the photo interpretation of aerial stereo pairs from 1963 to 1988 , horizontal displacements of the ground surface in the period 1963-1988 were detected in a range 3-6 m (average 12$24 \mathrm{~cm}$ per year) (Mihalić Arbanas et al. 2014). Monitoring results of recent movements from the period 2010-2012 at the 35 stable geodetic points shows very similar movement directions to historical data (Fig. 3).

The Kostanjek Landslide monitoring system encompasses approximately 40 sensors for the monitoring of landslide movement and landslide causal factors. Figure 4 provides the layout of the sensor network installed at the Kostanjek Landslide (Krkač et al. 2014a, b, c). The monitoring system consists of various sensors for the measurement of: (1) external triggers (1 rain gauge and 7 accelerometers); (2) displacement/deformation/activity (15 GNSS sensors, 7 extensometers, 4 borehole extensometers and 1 inclinometer); (3) hydrological properties (3 pore pressure gauges and 3 water level sensors in boreholes and domestic wells, 2 water level sensors at outflow weirs).

A Trimble GNSS monitoring system consists of fifteen double-frequency NetR9 TI-2 GNSS reference stations with Zephyr Geodetic 2 GNSS antennas installed on each of GNSS reference points. GNSS receivers are fixed to $4 \mathrm{~m}$
Fig. 3 Recent horizontal displacements (yellow arrows) at the Kostanjek landslide area in the period 2010-2012 (Županović et al. 2012) compared with historical horizontal displacement (white arrows) for the period 1963-1988 (Ortolan and Pleško 1992). Red line depicts Kostanjek landslide outline according to Ortolan (1996)

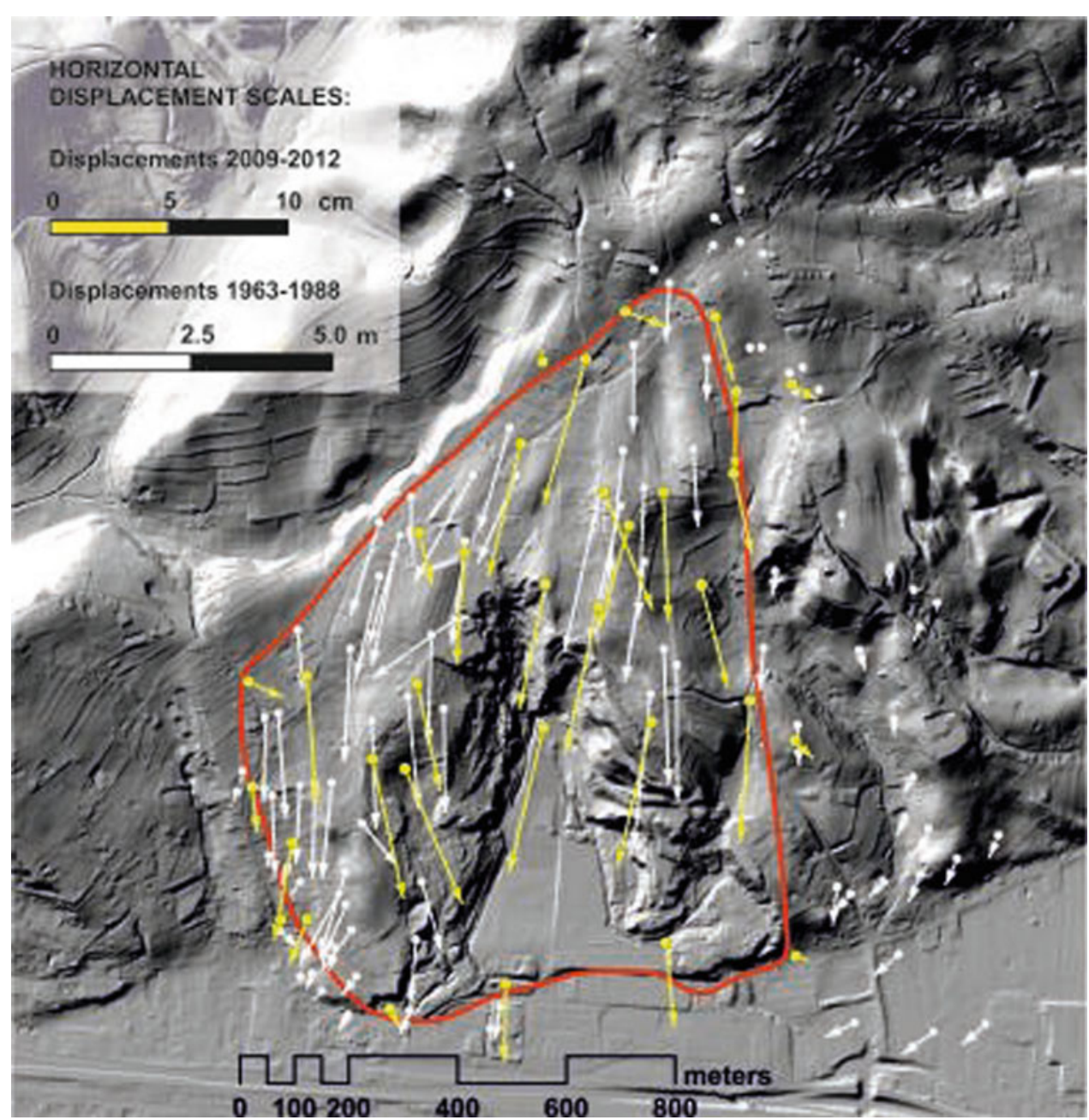


Fig. 4 Sensor network at the Kostanjek landslide area established in the framework of Japanese-Croatian SATREPS FY2008 scientific joint research project (Krkač et al. 2014a)

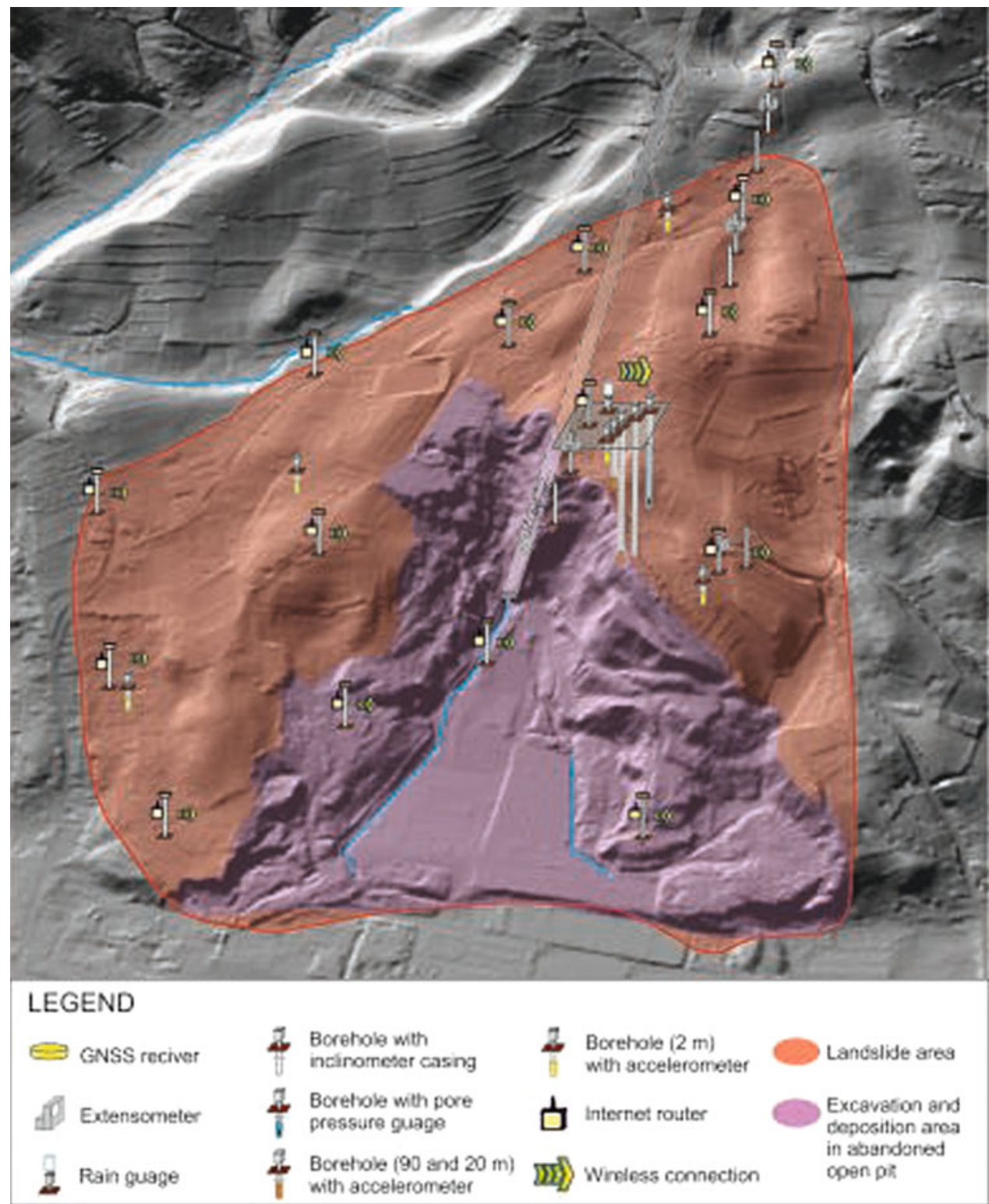

high poles with $1 \mathrm{~m}$ deep reinforced foundations. All monitoring stations are supplied with electricity from public network. Recievers collect GNSS raw data and deliver this data in real-time, over communication lines (using routers), to Trimble 4D Control software (T4DC) installed on an application/data server in a data center at the Faculty of Mininig, Geology and Petroleum Engineering UNIZG. GNSS receivers provide data on absolute positions of surficial points with precisions in the range of $\mathrm{cm}$ to $\mathrm{mm}$ (Krkač et al. 2014a). To be able to calculate very precise coordinates of 15 GNSS reference stations at the landslide area, the system needs at least one GNSS reference stations outside of the landslide zone located in Gornji Stupnik, which is $7 \mathrm{~km}$ away from Kostanjek (Krkač et al. 2014a).
The long- and short-span wire extensometers, type NetLG-501E Osasi, provide data on absolute deformation with submillimetre-level precision. Five long-span extensometers are placed from the top of the most stable point above the landslide; one short-span extensometer is placed perpendicular to the left landslide flank; two long-span extensometers are installed to cross the crown of an artificial steep slope where the highest magnitude of displacement is expected; and one short-span extensometer is installed in the underground, in a tunnel which crosses the sliding surface.

One inclinometer casing is installed in a $100 \mathrm{~m}$ deep vertical borehole in the middle of the landslide for measurements of the inclination of the pipe by a high-precision probe. The depth of the present-day major active shear 
surface is at $62.5 \mathrm{~m}$ (determined on the basis of two measurements, in May 2012 and February 2013). There is also some evidence of shallower sliding in the same borehole, at an approximate depth of $30 \mathrm{~m}$ (Krkač et al. 2014a).

The geophysical measurement sensor network encompasses seven accelerometers installed inside the landslide area for the purpose of (i) monitoring local micro-earthquake activity in the landslide area; (ii) monitoring regional earthquake activity, including strong motion; and (iii) monitoring of any ground tremors associated with the landslide, including possible ground inclination. This is a low cost and hi-fidelity broad-band monitoring system consisting of three-component MEMS accelerometer and three-channel autonomous broadband digital recorders with GPS to keep accurate synchronization between each other. A Seismic Source DAQ3-3 3CH high-fidelity digital logger with accurate GPS clocking enables continuous recording, with data harvesting by the attached USB memory every three weeks.

Three accelerometers (Colibrys SF1500S.A) are installed in three boreholes at the central monitoring station in the middle part of the landslide: one is in $90 \mathrm{~m}$ deep borehole below the sliding surface; one is in a $20 \mathrm{~m}$ deep borehole inside the landslide body; and one is in a shallow borehole near the surface. Four accelerometers (Colibrys SF3000L) are installed near the surface, in shallow boreholes at depths of approximately $1.5 \mathrm{~m}$ (Krkač et al. 2014a, b).

Monitoring sensors started recording landslide movements and one of the most active period was landslide reactivation due to external triggers in the winter period of 2012/2013. During the period from September 2012 to March 2013 the total cumulative precipitation was $793.7 \mathrm{~mm}$ and horizontal displacements were in the range of 4-20 cm (Mihalić Arbanas et al. 2014). The installed monitoring sensor network proved to provide reliable data for the establishment of relations between landslide causal factors and landslide displacement rates aimed at establishing threshold values for early warning system. Monitoring results from the winter period of 2012/2013 has been described in Krkač et al. (2014b, c).

Results of 2-year (2013-2014) monitoring at the central station, consisting of movement observations gathered by GNSS station (GNSS 08) and GWL depth observations gathered by water level sensor (WLS 01), together with precipitation data from Zagreb Grič meteorological station, located $9 \mathrm{~km}$ east of Kostanjek, were used for the establishment of the phenomenological model for the prediction of landslide movements (Krkač 2015).

The established phenomenological method enabled the prediction of slow landslide movements by means of landslide velocity and displacements from the precipitation data. The described method encompasses the modeling of groundwater level change rate from the daily and historical precipitation data followed by modeling of landslide velocity from the predicted daily groundwater level depths (calculated from groundwater level change rates). The modeling was performed using random forests, which enabled the evaluation of model parameter importance and development of the prediction model (Krkač 2015, 2016).

The model is established on 2-year monitoring data from the Kostanjek landslide, enabling the prediction of cumulative landslide displacements for periods up to 30 days (Fig. 5). The rainfall-groundwater level depth model was developed using 75 variables placed in six main groups: (1) antecedent precipitation, (2) effective precipitation, (3) precipitation events, (4) modified precipitation, (5) time periods since a certain precipitation event, and (6) climatological indexes. The groundwater level depth-landslide movement model was developed using 10 variables belonging to four main groups: (1) groundwater level depth,
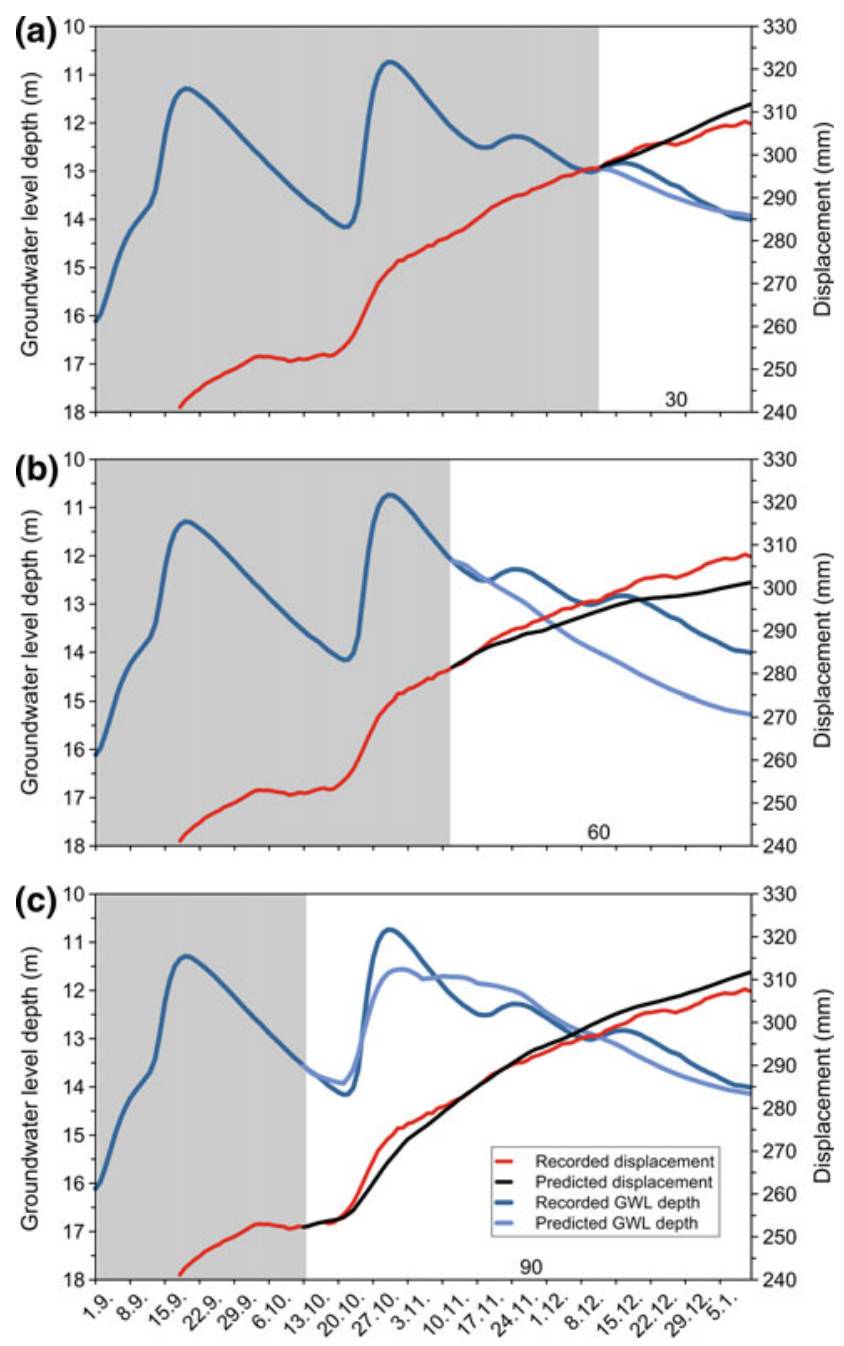

Fig. 5 Prediction of landslide displacements from predicted groundwater levels for periods of a 30 days, b 60 days, and c 90 days with displacement record (GNSS 08) (Krkač et al. 2016) 
(2) groundwater level change rate, (3) groundwater change acceleration, and (4) climatological indexes. The most important predictors for movement prediction are groundwater level depth, 7-day groundwater level change rate, and groundwater level change rate on the day after the day for which velocity is predicted.

Random forests prove to teach different patterns of landslide behavior under various conditions, which can be described by a large number of variables. Considering the described reliability of the prediction results, simplicity, and robustness, a random forests is proposed for application in the prediction of landslide movements. Automated predictions updated on a daily basis would produce improved everyday predictions, which are an important source of reliable information for decisions related to crisis management in the case of risky landslide movements (Krkač et al. 2016).

\section{Landslide Identification and Mapping}

The activities of Working Group on Landslide Mapping (WG3) are aimed at the development of landslide inventories using direct sensing and remote sensing techniques followed by the development of methodologies of landslide hazard analysis and zonation. Software and hardware, as well as input data (including stereo pairs of aerial photos, digital elevation models, Light Detection and Ranging (LiDAR) data and satellite images) have been donated by the Japanese government for three pilot areas in Croatia: two in Primorsko-Goranska County (the Rječina River Basin and the Dubračina River Basin) and one in the City of Zagreb (a hilly area of Medvednica Mt.).
Hilly Area of the Medvednica Mt. (City of Zagreb)

The hilly area of the southern foothills of Medvednica Mt. of $180 \mathrm{~km}^{2}$ is mostly urbanized and densely populated. The elevations in this area range from 115 to $612 \mathrm{~m}$ a.s.l., the prevailing slope angles (59\%) range from $6^{\circ}$ to $24^{\circ}$ and $84 \%$ slopes have slope angles $>3^{\circ}$ which are potentially prone to sliding. The dominant types are small and shallow landslides that mostly endanger residential structures and roads. The area is composed of Upper Miocene and Quaternary sediments (Fig. 6). The Upper Miocene deposits are stratified sands, silts and marls, with moderately to slightly-inclined bedding (bedding slope angle in range of $10^{\circ}-20^{\circ}$ ). The top parts of Miocene deposits are fine-grained soils, mostly silts. The Quaternary deposits are heterogeneous mixtures of unfoliated, mostly impermeable clayey-silty soils. The geologic contact between the Miocene sandy-silty soils and the Miocene or Quaternary clayey-silty soils is highly susceptible to sliding. The most frequent triggering factors are rainfall and man-made activities (Mihalić and Arbanas 2013).

The objective of identification and mapping of landslides at the area of hills of Medvednica Mt. was landslide inventory mapping, based on remote sensing. One of the task was to find technology appropriate for determination of landslide boundaries at the ground surface of very small to moderately large landslides (primarily $<1000 \mathrm{~m}^{2}$ ) mostly covered by deciduous vegetation and partially masked by urbanization. Part of project activities was also identification and mapping of landslides using conventional visual interpretation of stereoscopic aerial photographs (Podolszki 2014). Innovative method applied at the same pilot area was analysis of surface morphology with very-high-resolution

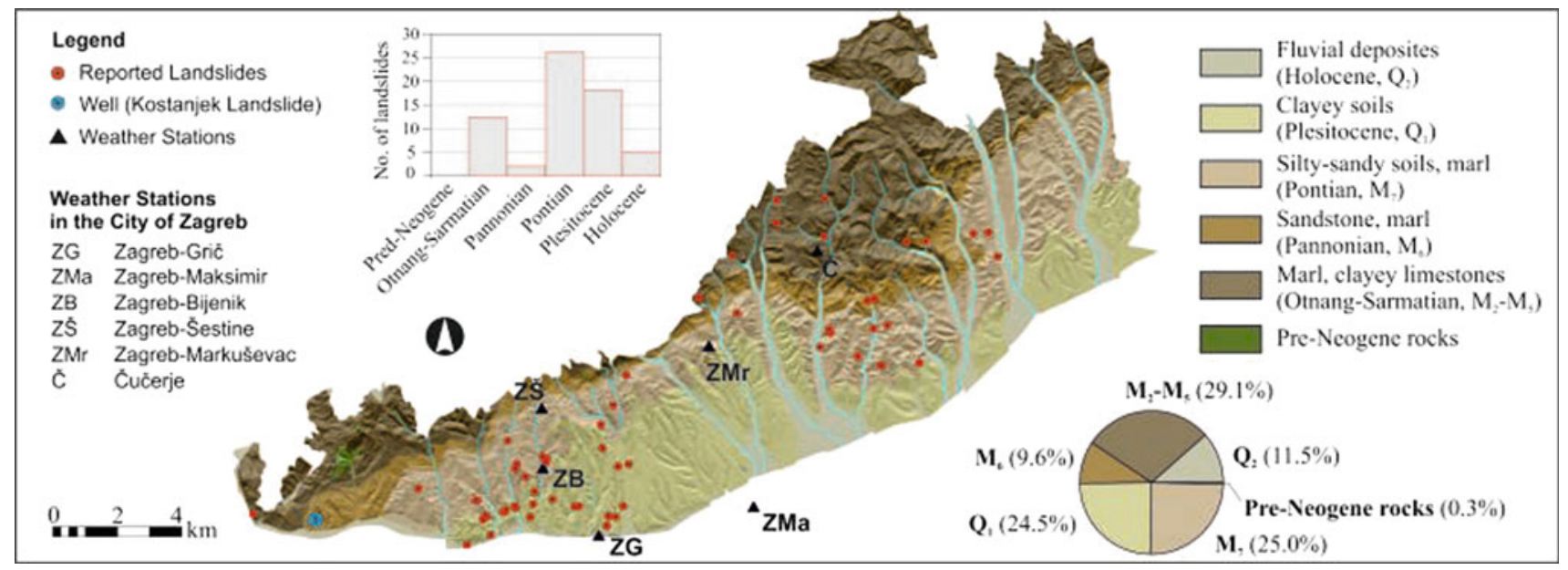

Fig. 6 Precipitation triggered landslide inventory map for the period from 1st January to 7th April 2013 (Bernat et al. 2014a). Landslides are depicted by dots on generalized geological map together with weather stations and one well where continuous water level measurement is available (Krkač et al. 2014a). Pie chart shows the relative distribution of main stratigraphic units; histogram shows the number of (re) activated landslides per stratigraphic unit 


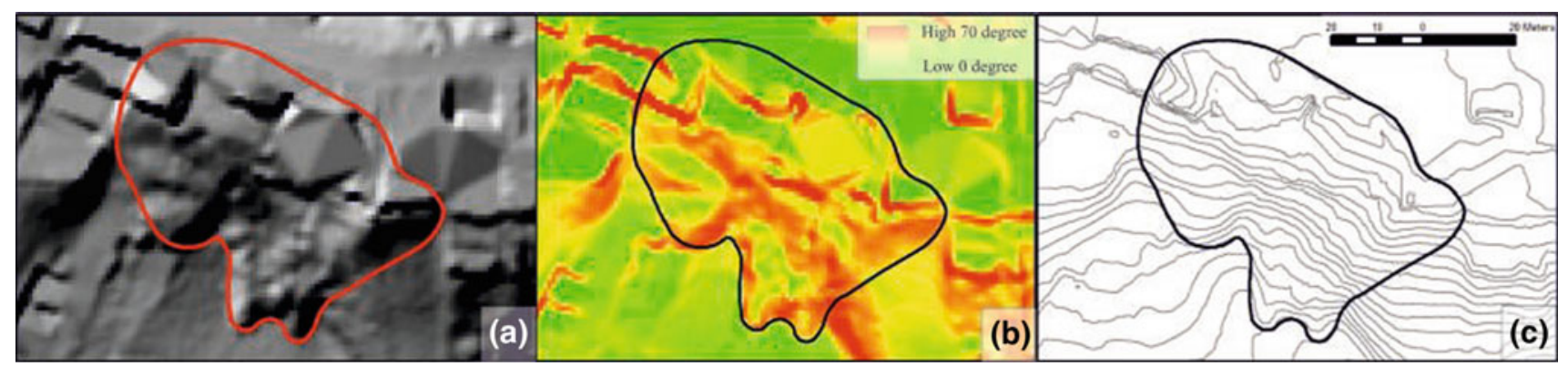

Fig. 7 Composite displays of three different topographic derivative maps of the Črešnjevec landslide. The estimated extent of displaced mass has a red and black contours: a Hillshade map generated and draped over a bare earth DEM. b Slope map showing areas of high slope angle in warmer colors (red, orange, yellow) and areas of low slope angle in cooler colors (green). c Contour map generated with a $1 \mathrm{~m}$ contour spacing (Mihalić Arbanas et al. 2014) digital elevation models (DEMs) captured by airborne LiDAR (Light Detection and Ranging) (Mihalić and Arbanas 2013).

For the LiDAR data that are used in the project, a test flight (covering $24 \mathrm{~km}^{2}$ ) took place in April 2011 and a flight over the entire study area $\left(180 \mathrm{~km}^{2}\right)$ was undertaken in December 2013, which corresponds to periods after leaf fall in Croatia. LiDAR ground-surface measurements were acquired at an average density of five points per square meter. The raw data were post-processed and a 1-m resolution bare earth DEM was interpolated. Slope maps, contour line maps and hillshade maps were created from the DEM by using standard tools in the ArcGIS. A contour line map was created with 1-m intervals. Landslide identification was performed by visual analysis and interpretation of the representation of the topographic surface (Mihalić Arbanas et al. 2016).

The visual identification of the landslides was based on the recognition of landslide features on three topographic derivative maps: a contour map with a 1-m contour span, a hillshade map and a slope map. The mapped landslides were characterized by visible main landslides features such as main scarps, landslide boundaries and toes, zones of depletion and zones of accumulation.

Figure 7 presents one of the typical identification results obtained for the previously known Črešnjevec landslide, which is characterized by multiple reactivations of the upper part of the slope after unsuccessful remedial measures in 2004. The red and black lines depict the contours of an active slow-moving retrogressive landslide. Combining the hillshade, slope and contour maps from the airborne LiDAR data easily distinguishes only the lower part of the displaced mass, while the main scarp, which has a vertical displacement of approximately $10-30 \mathrm{~cm}$, is not clearly expressed. The identification of the landslide contours in the built-up area of the Črešnjevec landslide with airborne LiDAR data was followed by field checking and mapping (Mihalić Arbanas et al. 2014, 2016).

\section{Dubračina River Basin (Primorsko-Goranska County)}

The Dubračina River Basin represents a lower part of the elongated unique morphostructural unit Rječina ValleyBakar Bay-Vinodol Valley. The central part of the Vinodol Valley, which belongs to the Dubračina river catchment area, is about $13 \mathrm{~km}$ long and $1.5-5 \mathrm{~km}$ wide and stretches parallel to the Adriatic coast in the northwest-southeastern direction. The Vinodol valley has an asymmetrical cross section in this part with a prominently longer northeastern and shorter southwestern slope. The Dubračina riverbed is mostly situated on the littoral ridge (Benac et al. 2010).

The elevations in this area range from 5 to $920 \mathrm{~m}$ a.s.l., and the prevailing slope angles $(58 \%)$ between $5^{\circ}$ and $20^{\circ}$ are present in the middle part of the basin. Along the northeast and southeast border, the valley is surrounded by steep cliffs whose peaks reach $922 \mathrm{~m}$. The basin has an asymmetrical cross section (in the NE-SW direction) with a prominently longer northeast slope and a shorter southwest slope. The ridge peaks on the southwest side reach $357 \mathrm{~m}$, and the valley bottom is $30 \mathrm{~m}$ a.s.l. Karstified carbonate rocks (mostly Upper Cretaceous and Paleogene limestones) are visible at the top of the slopes and cover $55 \%$ of the basin area. The clearly marked rocky scarps represent the rim of the karstic plateau at the top of the NE slopes (Benac et al. 2010). Siliciclastic rocks of Eocene age (siltstones and sandstones interlayered with breccia, conglomerates and limestone) are situated in the lower slopes and in the bottom of the valley, but they are mostly covered by slope deposits (Đomlija et al. 2014).

Figure 8 presents seven geomorphological units distinguished in the Dubračina River Basin: alluvial plain; proluvium; terrace slope; hills; mountain slope; limestone wall; and karst plateau. Basic characteristics of the outlined landform units are given with regard to geological settings, geomorphological features and hydrological conditions in Bernat et al. (2014b). The main geological hazards in the 
Dubračina River Basin are active geomorphological processes in the form of different types of slope movements and erosion processes.

Several types of slope movements and erosional phenomena are identified that are characteristic for delineated landforms of the Dubračina River Basin. In this phase of investigation, the aim was only to identify all types of slope movement processes that are characteristic for each landform unit. Types of identified active and historical geomorphological processes and phenomena are the following: active and historical slides, creeping phenomena, active gully erosions, screes, rockfalls, topplings, and traces of historical debris flows (Bernat et al. 2014b).

\section{Rječina River Basin (Primorsko-Goranska County)}

The Rječina River basin is located in continental part of the Primorsko-Goranska County, and it stretches in NW-SE direction (Fig. 8). Total area of the Rječina River Basin is $22 \mathrm{~km}^{2}$ and it is mostly unurbanized, with approximately 12 settlements. Current land-use at the area of the Basin is as follows: $19.5 \mathrm{~km}^{2}$ is forest and semi natural areas, $2 \mathrm{~km}^{2}$ are artificial surface (roads and buildings), and $\sim 1 \mathrm{~km}^{2}$ are other use types. Altitude of this area ranges from 0 to $600 \mathrm{~m}$ above sea level, and the slope angles mostly range from $0^{\circ}$ to $30^{\circ}$ (88\% area, Fig. 9). Along the main watercourse, three different geomorphological zone exist: first from the river source at the foot of Gorski Kotar Mountains to the Lukeži Village; second zone from the Lukeži Village to the canyon entrance near the Pašac Bridge; and third from the canyon area to the alluvial plain on the river mouth in the centre of the City of Rijeka (Benac et al. 2011).

The most interesting part of the basin is the central part of the Rječina River Valley regarding active geomorphological processes and historical landslide phenomena. This part of the valley is $3 \mathrm{~km}$ long and $0.8-1.5 \mathrm{~km}$ wide. Cross section of the valley is symmetrical with bottom at $150-200 \mathrm{~m}$

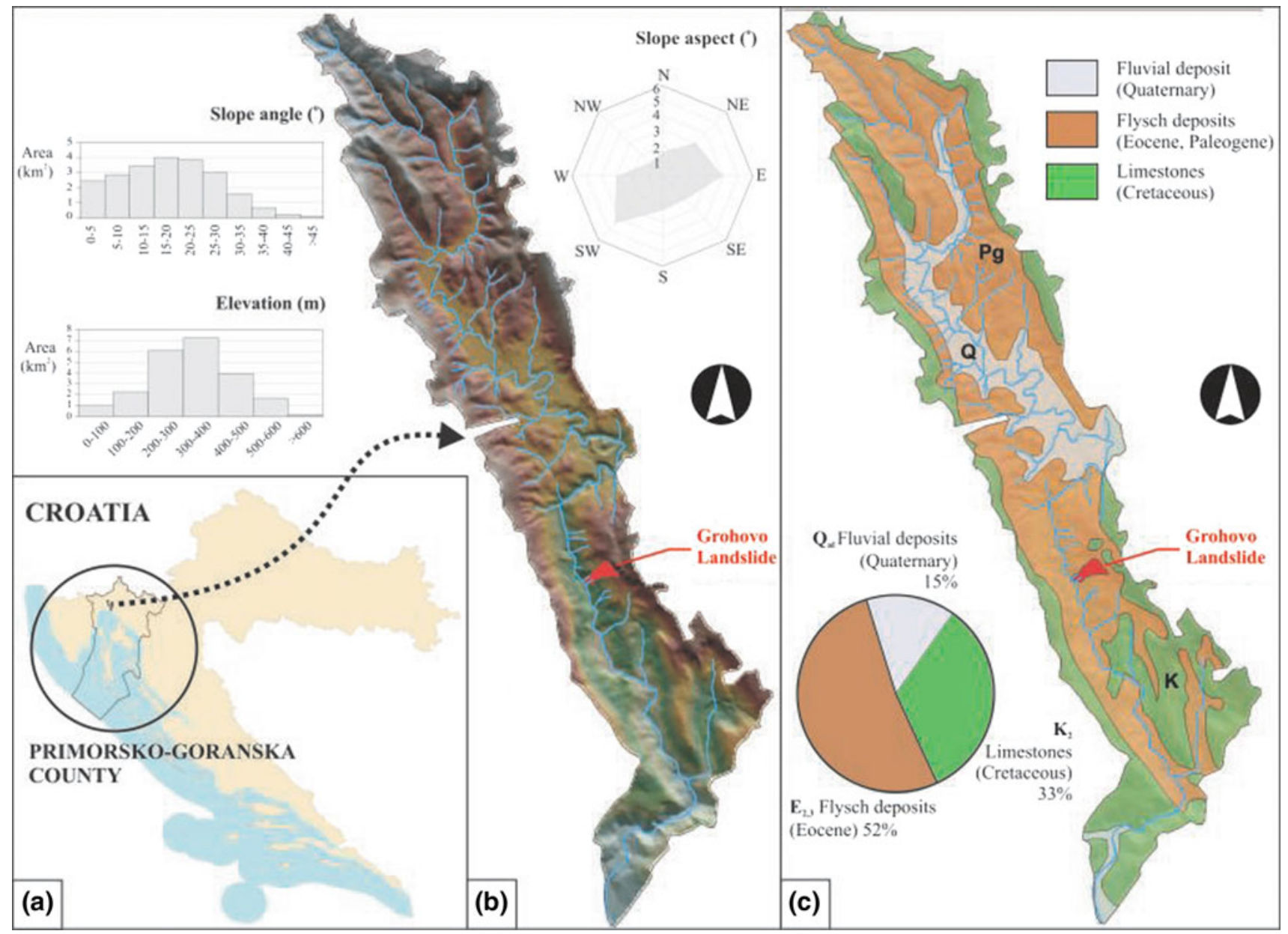

Fig. 8 Thematic data available for the Rječina River Basin. a Geographic location; b elevation map from the $25 \mathrm{~m} \times 25 \mathrm{~m}$ DEM. Histograms show the distribution of elevation and slope angle computed from the DEM. Rose diagram shows distribution of slope aspect (in $\mathrm{km}^{2}$ ). c geological map showing the main stratigraphic units (Mihalić and Arbanas 2013) 
Fig. 9 Oblique aerial view created from the LIDAR-derived bare-earth DEM of the Rječina River Valley. Landslide features of an unnamed landslide can be clearly identified. Yellow borders contour historical landslides from 1885 and 1750 on the left side and 1893 on the right side. Red coloured zone is area of reactivated landslide from 1996 Red borders contour younger landslides (Arbanas et al. 2014a)

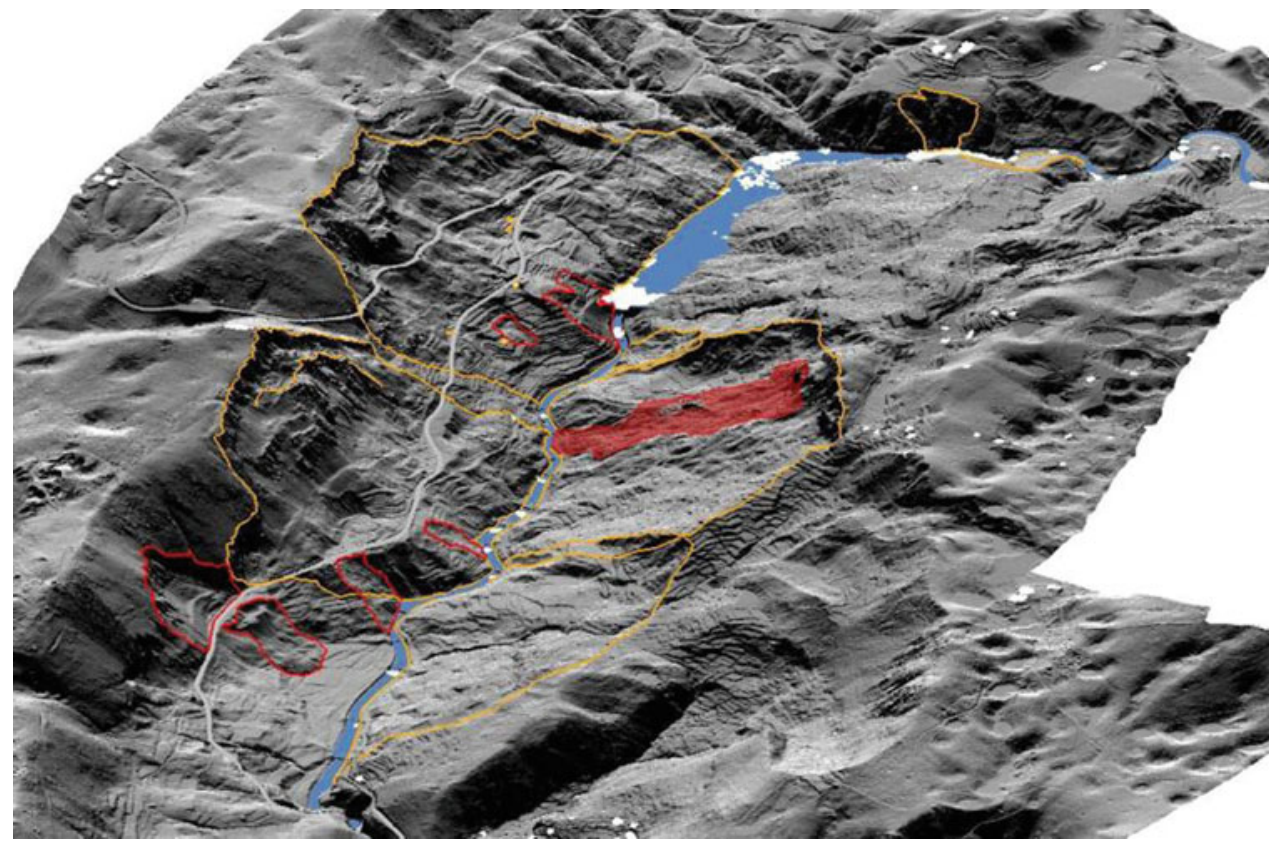

above sea level, and the peak height at $432 \mathrm{~m}$ in the SW and $412 \mathrm{~m}$ in the NE. Karstified limestone rock masses are visible on the top of the slope in the central part of the valley, while the flysch rock mass are placed in the lower slopes and at the bottom of the valley. The clearly marked rocky scarps represent the rim of the karstic plateau above the SW slopes and partially the NW slopes which could be seen at simplified geological map (Fig. 8). Both slopes are covered with potentially unstable superficial deposits. This area is geodynamically very active, and landslides are the main geological hazard. Different types of slope movements can be distinguished: relict and dormant deep seated landslides, reactivated rockfalls from limestone cliffs at the top part of the slope, reactivated sliding of coluviall deposits (predominantly coarse fragments and limestone blocks) over the flysch bedrock (Benac et al. 2005).

Numerous historical descriptions, figures, photographs and maps describing landslides were found in the Croatian State Archive in Rijeka which provides evidence of the occurrence of landslides in the Rječina Valley near the Grohovo Village. Sliding was first documented in 1767, when numerous landslides and rockfalls in the Rječina River Valley were caused by the 1750 earthquake. A large landslide occurred on the southwestern slope in 1870 , and after reactivation of the slide in 1885 part of the Grohovo Village was buried by a rock avalanche. Next large landslide occurred in 1893 on the northeastern slope of the Rječina River Valley at the location of the recent landslide, and the Rječina River channel was shifted to the south by approximately $50 \mathrm{~m}$. Numerous landslides occurred during the first half of the 20th century but did not cause significant damage to structures on the river banks. New problems with landslides in the Rječina valley occurred during construction of the Valići Dam in 1960, when landslides appeared on the northeast slope near the dam. The large landslide, so called the Grohovo Landslide, occurred in December 1996 at the location of the landslide from 19th century on the northeast slope described in the chapter The Grohovo Landslide monitoring system.

With the knowledge about numerous landslide occurrences in the Rječina River Valley in the history and without landslide inventory which would offer insight in real landslide distribution in the area, the first step for necessary analyses was identification of existing landslides in the research area and assessment of their features (Mihalić Arbanas and Arbanas 2014). As an appropriate technique for landslide identification in the Rječina River Valley the analyses of very-high resolution DEMs obtained by airborne laser scanning in combination with field mapping was chosen. The visual identification of landslides is based on the recognition of landslide features on the following types of topographic derivative maps: contour map, hillshade map, slope map, curvature map and topographic roughness map. The main landslide features (main scarp, flanks etc.) are checked by field mapping.

This procedure was repeated for identification of all known historical landslides in the valley on the basis of historical descriptions and all these landslides are located and determined. During very-high resolution DEMs analyses a notable number of unknown landslides was identified and most of them are completely hidden covered by vegetation. Time of their occurrence is also unknown but scars and expression of their features indicate on relatively young phenomena. Historical landslides in the Rječina River 
Valley are major instabilities and their volumes vary from 6.1 to 25 million $\mathrm{m}^{3}$, while younger landslides are significantly smaller with volumes from 10 thousand to 3 million $\mathrm{m}^{3}$, and mostly occurred as reactivated parts of the older landslides. When all these landslides are presented on same DEM it is clearly visible that the both slopes of the valley are intensively affected by sliding, Fig. 9 (Arbanas et al. 2014a).

\section{Soil Testing and Landslide Simulation}

\section{Soil Testing}

Detailed laboratory soil testing as a base for prediction of landslides behaviour are performed in a ring-shear apparatus that is designed for testing under static and dynamic conditions for deep seated large landslides in Croatia. The ring-shear apparatus was designed initially to investigate the residual shear resistance under the drained condition along the sliding surface at large shear displacements in landslides because it allows unlimited deformation of the specimen. Professor Sassa with his team has developed the undrained high speed ring shear apparatus to reproduce a rapid landslide motion after failure and to measure the generated pore pressure and the shear resistance mobilized on the sliding surface during motion (Sassa et al. 2003, 2004; Okada et al. 2004; Fukuoka et al. 2006). The new developed apparatus is (Fig. 10), compared to previous ones, much smaller in dimensions and has higher performances. It can keep undrained condition up to $1 \mathrm{MPa}$ of pore water pressure, up to 3 times more than in previous versions of apparatus and load normal stress up to $1 \mathrm{MPa}$. This makes it suitable for testing of soil samples in stress condition as on surfaces of rupture in deep seated landslides.

The soil samples from the Grohovo Landslide were taken from the flysch outcrop in the central part of the landslide body. Speed control test was conducted under constant shear speed of $0.002 \mathrm{~cm} / \mathrm{s}$ in undrained conditions. Sample was sheared until the shear displacement reached $1.0 \mathrm{~m}$ and the steady state conditions were obtained. As a results of this test, the basic parameters values (peak, mobilized and apparent friction angle, so as cohesion) as well as steady state normal and shear stress of soil sample were obtained (Oštrić et al. 2012; Vivoda et al. 2014).

\section{The Integrated Model of Landslide Simulation}

The LS-Rapid software is the first landslide simulation model possible to integrate the whole process of stable state, failure, post-failure strength reduction, motion and deposit of sliding mass (Sassa et al. 2010, 2014). In the simulation, the friction angle and cohesion will be reduced from their peak values to the normal motion time values within the source area in the determined distribution of the unstable mass. The strength reduction will be started in the moment when the travel length will become equal to shear displacement at the start of strength reduction. The strength reduction will be completed and the normal motion simulation will be started when the travel length will reach the value of shear displacement at the end of strength reduction.

The topography of the Rječina River Valley (Fig. 11) was determined using original DEM data. The limestone rock mass is situated at the top of the slopes, while the siliciclastic
Fig. 10 New developed portable ring-shear apparatus designed for testing under static and dynamic conditions for deep-seated large landslides in Croatia

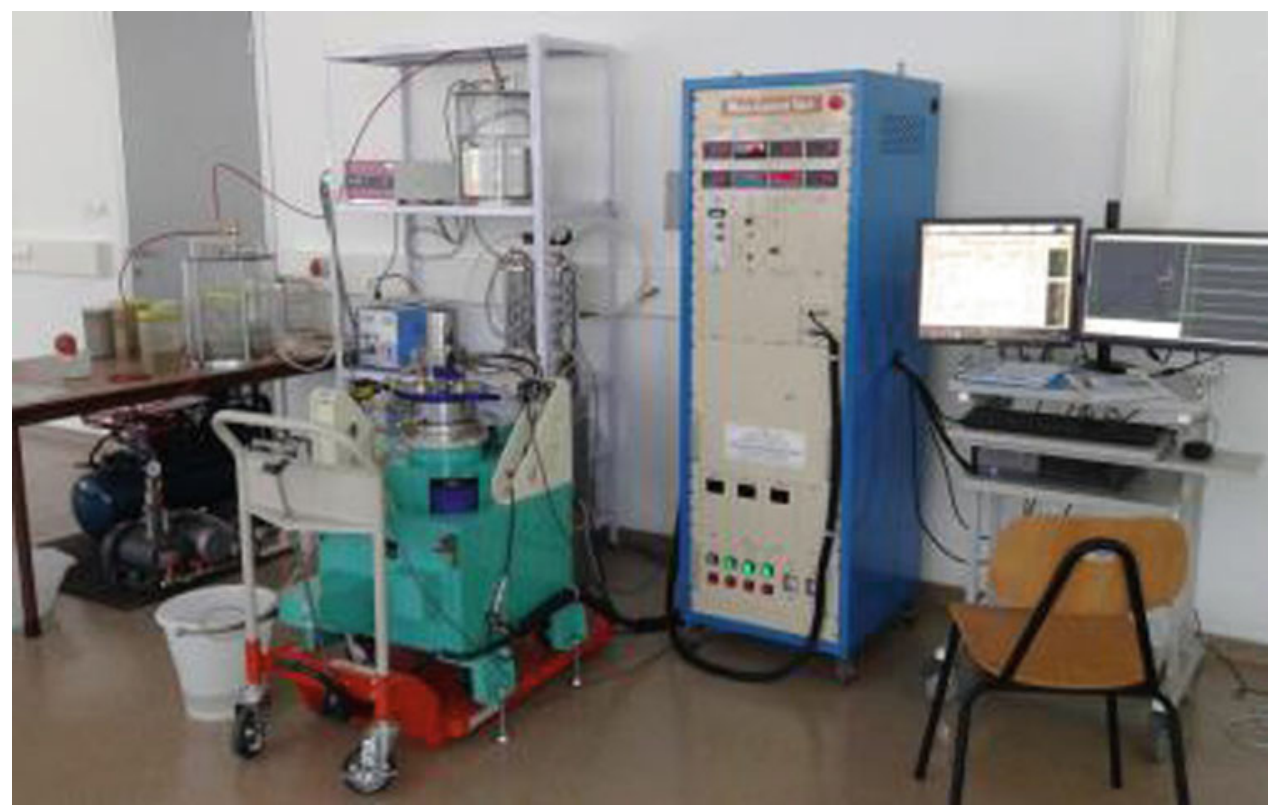




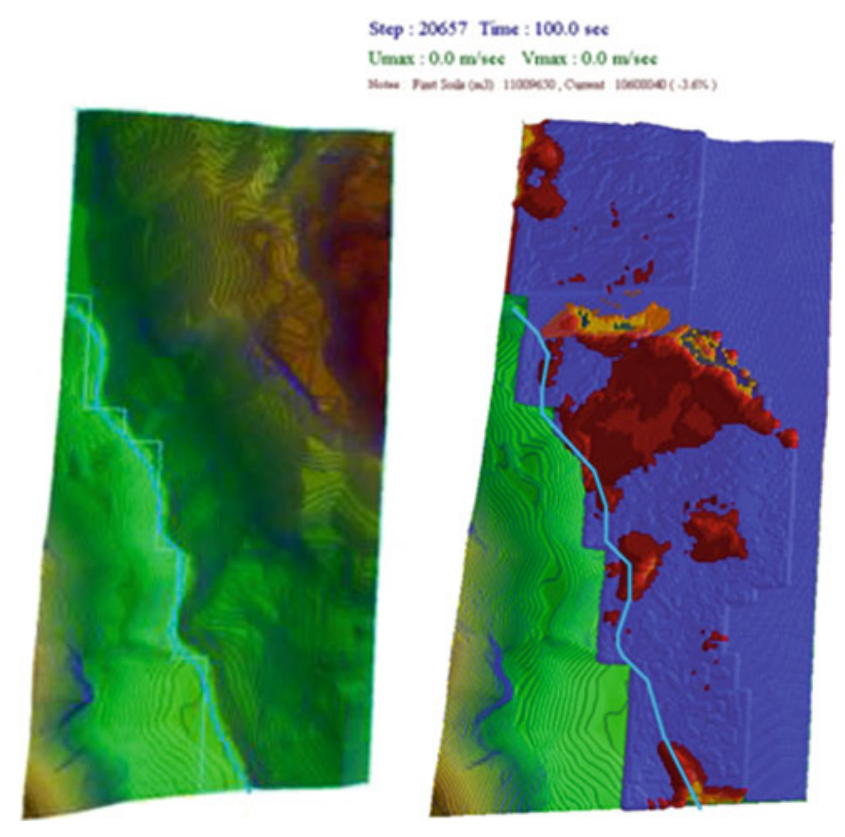

Fig. 11 Numerical simulation of the Grohovo landslide using LS-Rapid software (Vivoda et al. 2014). Digital elevation model on the left side and displaced mass on the right side

rocks and flysch are situated on the lower slopes and the bottom of the valley. Depth of the sliding mass varies from 3 to $10 \mathrm{~m}$ over the flysch bedrock and from 0.0 to $0.5 \mathrm{~m}$ over the limestone rock mass. This assumption is based on knowledge that the existing slip surface is positioned at the contact between superficial slope deposits and flysch bedrock (Benac et al. 2005). The long-term rainfalls and consequent ground water level rising were the main triggering factor for the existing landslide occurrences in the Rječina River Valley. This ground water level rising in the model was expressed by excess of the pore pressure ratio until the value of $r_{u}=0.60$, which is correspondent to the ground water level equal to terrain surface (Vivoda et al. 2014).

The simulation results are shown on Fig. 11. The blue colored zones represent the stable areas or areas with movement velocity less than $0.1 \mathrm{~m} / \mathrm{s}$. The orange and red colored zones represent areas where the sliding occurred. The results of conducted simulation very clearly suggest that the new slides, caused by future unfavorable hydrogeological conditions, would be occurred in the area of the existing Grohovo Landslide and this fact confirm the correct selection of the Grohovo Landslide for monitoring and early warning system establishment.

Gradiški et al. (2014) analyzed behavior of the Kostanjek landslide (Fig. 12) using the LS-RAPID software. Existing landslide model from Ortolan (1996) was modified on the basis of monitoring results by creation of ellipsoidal sliding surface with maximum depth of $65 \mathrm{~m}$ in the central part of the landslide body (according to maximal displacements). For more reliable interpretation of the sliding surface depths, additional subsurface investigations and monitoring are necessary. Parameters used for these analyses were determined from drained test of samples in ring shear apparatus.

According to the results of the analyses, the most unstable part of the landslide is the central part of the landslide body, i.e. the slopes of the abandoned open marl pit. In the analyses the movements started in the central part of the landslide body, and the failure area will expand around the initial failure zone. At the end of simulation the area of the whole landslide mass corresponds to the landslide contour from historical landslide model according to Ortolan (1996). This is also in accordance to the new surface deformations (cracks, bulging, and subsidence) developed by very recent landslide movement in 2013 (Fig. 12) (Mihalić Arbanas et al. 2014).

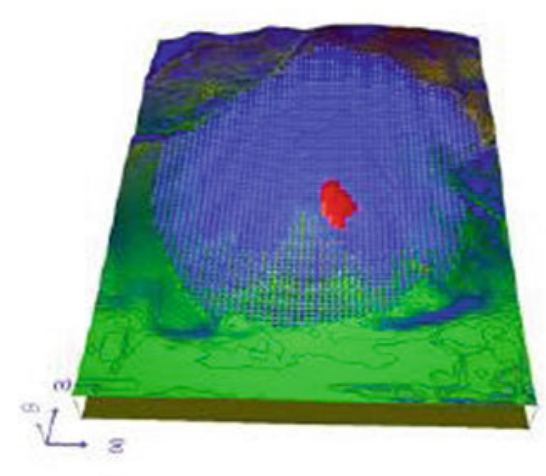

$r_{u}=0.3$

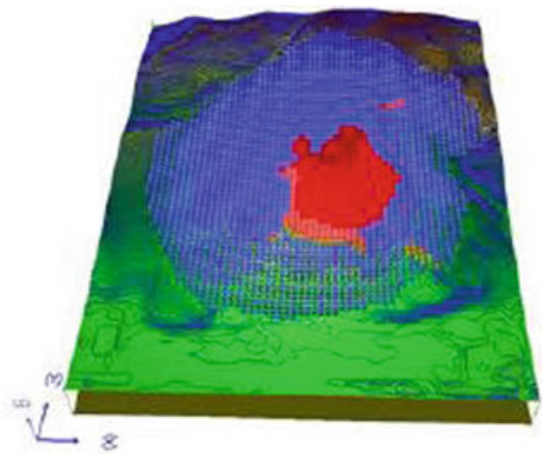

$r_{\mathrm{u}}=0.5$

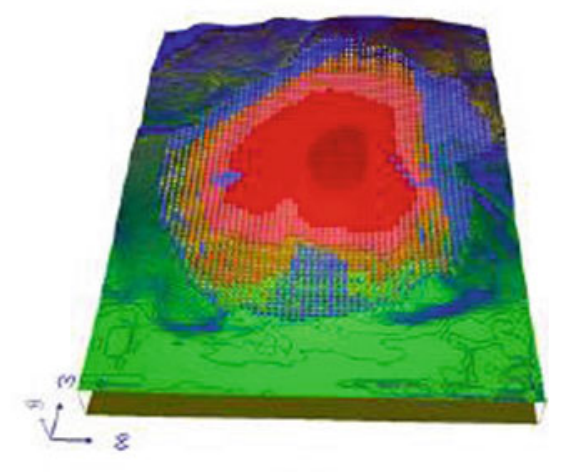

$r_{u}=0.8$

Fig. 12 The Kostanjek landslide simulation at $r_{u}=0.3, r_{u}=0.5, r_{u}=0.8$ (Gradiški et al. 2014) 


\section{Conclusions}

The Croatian-Japanese joint research Science and Technology Research Partnership for Sustainable Development (SATREPS) project 'Risk Identification and Land-Use Planning for Disaster Mitigation of Landslides and Floods in Croatia' was performed from 2009 to 2014. Key objectives of the project were landslides and floods hazard analysis and the development of guidelines for use in urban planning. The main Japanese partner institutions in the Project were Research Center for Natural Hazards and Disaster Recovery at Niigata University, Disaster Prevention Research Institute of Kyoto University (DPRI) and the International Consortium on Landslides (ICL). Three Croatian universities, the University of Rijeka (Faculty of Civil Engineering), the University of Zagreb (Faculty of Mining, Geology and Petroleum Engineering and Faculty of Agriculture) and the University of Split (Faculty of Civil Engineering, Architecture and Geodesy) as well as the Croatian Geological Survey were Croatian partner institutions in the project. The five-year project, started in 2009 and completed in 2014, involved about 15 researchers from Japan and included collaborative research conducted in Japan and Croatia to evaluate and mitigate landslide and flood hazards and risks in Croatia.

The project activities are organized into three working groups: Working Group on Landslides (WG1), Working Group on Flash Floods and Debris Flows (WG2) and Working Group on Landslide Mapping (WG3). The aim of Working Group 1 on Landslides was to establish a methodology of comprehensive real time monitoring at two most important landslides in Croatia: the Grohovo Landslide in Primorsko-Goranska County and the Kostanjek Landslide in the City of Zagreb based on the results of previous investigations and new in situ and laboratory testing and behavior analysis so as a laboratory soil testing and numerical modelling of static and dynamic landslide behavior. The activities of Working Group 3 on Landslide Mapping (WG3) were aimed at the development of landslide inventories using direct sensing and remote sensing techniques followed by the development of methodologies of landslide hazard analysis and zonation in three pilot areas in Croatia: two in Primorsko-Goranska County and one in the City of Zagreb.

The results of the project were published at the four project workshops held in Dubrovnik (2010), Rijeka (2011), Zagreb (2013) and Split (2014). The project also resulted with regional cooperation and establishment of Adriatic Balkan Network of ICL and the third project workshop held in Zagreb (2013) was organized as the 1st Regional Symposium on Landslides in Adriatic Balkan Region.
Acknowledgements The results presented herein have been obtained with financial support from the Japan Agency for Science and Technology (JST) and the Japan Agency for International Cooperation (JICA) as a FY2008 SATREPS (Science and Technology Research Partnership for Sustainable Development) programme for 2008-2014. Co-financing was ensured from the Ministry of Science, Education and Sports of the Republic of Croatia, the City Office for Physical Planning, Construction of the City, Utility Services and Transport, City of Zagreb and the Emergency Management Office of the City of Zagreb and City of Rijeka. These supports are gratefully acknowledged.

\section{References}

Arbanas Ž, Jagodnik V, Ljutić K, Dugonjić S, Vivoda M (2012a) Establishment of the Grohovo Landslide monitoring system. Proceedings of the 2 nd workshop of the project risk identification and land-use planning for disaster mitigation of landslides and floods in Croatia, 15-17 December 2011. Rijeka, Croatia, pp 29-32

Arbanas Ž, Sassa K, Marui H, Mihalić S (2012b) Comprehensive monitoring system on the Grohovo Landslide, Croatia. Proceedings of the 11th international and 2nd North American symposium on landslides: landslides and engineered slopes: protecting society through improved understanding, June 2-8, 2012. Banff, Canada, pp 1441-1447

Arbanas Ž, Mihalić Arbanas S, Vivoda M, Peranić J, Dugonjić Jovančević S, Jagodnik V (2014a) Identification, monitoring and simulation of landslides in the Rječina River Valley, Croatia. Proceedings of the SATREPS Workshop on Landslides in Vietnam, Hanoi, Vietnam, pp 200-213

Arbanas Ž, Sassa K, Nagai O, Jagodnik V, Vivoda M, Dugonjić Jovančević S, Peranić J, Ljutić K (2014b) A landslide monitoring and early warning system using integration of GPS, TPS and conventional geotechnical monitoring methods. Proceeding of In proceeding of world landslide forum 3 , landslide science for a safer geoenvironment, vol: 2, methods of landslide studies, 13-16 June 2014. Beijing, China, pp 631-636

Benac Č, Arbanas Ž, Jurak V, Oštrić M, Ožanić N (2005) Complex landslide in the Rječina River valley (Croatia): origin and sliding mechanism. Bull Eng Geol Env 64(4):361-371

Benac Č, Mihalić S, Vivoda M (2010) Geological and geomorphological conditions in the area of Rječina river and Dubračina river catchments (Primorsko-goranska County, Croatia). Proceedings of 1st workshop of the Japanese-Croatian SATREPS FY2008 project, 22-24 November 2010. Zagreb, Croatia. pp 39-39

Benac Č , Dugonjić S, Vivoda M, Oštrić M, Arbanas Ž (2011) Complex landslide in the Rječina Valley: results of monitoring 1998-2010. Geologia Croatica 64(3):239-249

Bernat S, Mihalić Arbanas S, Krkač M (2014a) Inventory of precipitation triggered landslides in the winter of 2013 in Zagreb (Croatia, Europe). Proceedings of the 3rd world landslide forum, vol. 2, 2-6 June 2014. Beijing, China. pp 829-836

Bernat S, Đomlija P, Mihalić Arbanas S (2014b) Slope movements and erosion phenomena in the Dubračina River Basin: a geomorphological approach. Proceedings of the 1st Regional symposium on landslides in the Adriatic-Balkan region 'Landslide and flood hazard assessment', 6-9 Mar 2013. Zagreb, Croatia, pp 79-84

Đomlija P, Bernat S, Arbanas Mihalić S, Benac Č (2014) Landslide inventory in the area of Dubračina river basin (Croatia). Proceedings of the 3rd world landslide forum, vol. 2, 2-6 June 2014. Beijing, China. pp 837-842

Fukuoka H, Sassa K, Wang G, Sasaki R (2006) Observation of shear zone development in ring-shear apparatus with a transparent shear box. Landslides 3:239-251 
Gradiški K, Sassa, K, He B, Krkač M, Mihalić Arbanas S, Arbanas Ž, Oštrić M, Kvasnička P (2014) Application of integrated landslide simulation model using LS-rapid software to the Kostanjek Landslide, Zagreb, Croatia. Proceedings of the 1st regional symposium on landslides in the Adriatic-Balkan Region 'Landslide and flood hazard assessment', 6-9 Mar 2013. Zagreb, Croatia, pp 11-16

Han Q, Sassa K, Kan FM, Margottini C (2017) International programme on landslides (IPL): objectives, history and list of IPL projects. Advancing culture for living with landslides, vol 1 ISDR-ICL Sendai partnerships 2015-2025 (this volume)

Krkač M (2015) A phenomenological model of the Kostanjek landslide movement based on the landslide monitoring parameters. $\mathrm{PhD}$ thesis, University of Zagreb (in Croatian)

Krkač M, Mihalić Arbanas S, Nagai O, Arbanas Ž, Špehar K (2014a) The Kostanjek landslide-monitoring system development and sensor network. Proceedings of the 1st regional symposium on landslides in the Adriatic-Balkan Region 'Landslide and flood hazard assessment', 6-9 Mar 2013. Zagreb, Croatia, pp 27-32

Krkač M., Mihalić Arbanas S, Arbanas Ž, Bernat S, Špehar K, Watanabe N, Osamu N, Sassa K, Marui H, Furuya G, Wang C, Rubinić J, Matsunami K (2014b) Review of monitoring parameters of the Kostanjek landslide (Zagreb, Croatia). Proceedings of the 3rd world landslide forum, vol 2, 2-6 June 2014. Beijing, China, pp 637-645

Krkač M, Mihalić Arbanas S, Arbanas Ž, Bernat S, Špehar K (2014c) The Kostanjek landslide in the City of Zagreb: forecasting and protective monitoring. Proceedings of the XII IAEG congress, 1519 Sept 2014. Torino, Italy, pp 715-719

Krkač M, Špoljarić D, Bernat S, Mihalić Arbanas S (2016) Method for prediction of landslide movements based on random forests. Landslides (published online). doi:10.1007/s10346-016-0761-z

Mihalić S, Arbanas Ž (2013) The Croatian-Japanese joint research project on landslides: activities and public benefits. In: Sassa K, Rouhban B, Briceño S, McSaveney M, He B (eds) Landslides: Global Risk Preparedness. Springer, Heidelberg, pp 333-349

Mihalić Arbanas S, Arbanas Ž (2014) Landslide mapping and monitoring: review of conventional and advanced techniques. Proceedings of the 4th symposium of Macedonian association for geotechnics, 25-28 June 2014. Struga, Macedonia, pp 57-72

Mihalić Arbanas S, Krkač M, Bernat S, Arbanas Ž (2014) Landslide mapping and monitoring in the City of Zagreb (Croatia, Europe) Proceedings of the SATREPS workshop on landslides in Vietnam, Hanoi, Vietnam, pp 214-226

Mihalić Arbanas S, Krkač M, Bernat S (2016) Application of advanced technologies in landslide research in the area of the City of Zagreb (Croatia, Europe). Geologia Croatica 69(2):231-243
Okada Y, Sassa K, Fukuoka H (2004) Excess pore pressure and grain crushing of sands by means of undrained and naturally drained ring-shear tests. Eng Geol 75:325-343

Ortolan Ž, Pleško J (1992) Repeated photogrammetric measurements at shaping geotechnical models of multi-layer landslides. Rudarsko-geološko-naftni zbornik 4:51-58

Ortolan Ž (1996) Development of 3D engineering geological model of deep landslide with multiple sliding surffaces (Example of the Kostanjek Landslide). PhD thesis. Faculty of Mining, Geology and Petroleum Engineering, University of Zagreb, Zagreb (in Croatian)

Oštrić, M., Ljutić K., Krkač M., Setiawan H., He, B., Sassa, K. (2012) Undrained ring shear tests performed on samples from Kostanjek and Grohovo landslide. In: Sassa K, Takara K, He B (eds) Proceedings of the IPL symposium. Kyoto, Japan, pp 47-52

Podolszki L (2014) Stereoscopic analysis of landslides and landslide susceptibility on the southern slopes of Medvednica Mt. PhD thesis, Faculty of Mining, Geology and Petroleum Engineering, University of Zagreb, Zagreb, Croatia (In Croatian)

Sassa K, Wang G, Fukuoka H (2003) Performing undrained shear tests on saturated sands in a new intelligent type of ring shear apparatus. ASTM Geotech Test J 26(3):257-265

Sassa K, Fukuoka H, Wang G, Ishikawa N (2004) Undrained dynamic-loading ring-shear apparatus and its application to landslide dynamics. Landslides 1:7-19

Sassa K, Nagai O, Solidum R, Yamazaki Y, Ohta H (2010) An integrated model simulating the initiation and motion of earthquake and rain induced rapid landslides and its application to the 2006 Leyte landslide. Landslides 7(3):219-236

Sassa K, He B, Dang K, Nagai O, Takara K (2014) Progress in landslide dynamics. Proceeding of world landslide forum 3, landslide science for a safer geoenvironment, vol: 1 , methods of landslide studies, 13-16 June 2014. Beijing, China, pp 37-67

Savvaidis PD (2003) Existing landslide monitoring systems and techniques. Proceedings of the conference from stars to earth and culture, In honor of the memory of Professor Alexandros Tsioumis. Thessaloniki, Greece, pp 242-258

Vivoda M, Dugonjić Jovančević S, Arbanas Ž (2014) Landslide occurrence prediction in the Rječina River valley as a base for an early warning system. Proceedings of 1 st regional symposium on landslides in the Adriatic-Balkan Region "Landslide and flood hazard assessment", 6-9 Mar 2013, Zagreb, Croatia, pp 85-90

Županović L, Opatić K, Bernat S (2012) Monitoring of movements of the Kostanjek landslide using relative static method (GNSS technology). Ekscentar 15:46-53 (In Croatian)
Open Access This chapter is licensed under the terms of the Creative Commons Attribution 4.0 International License (http:// creativecommons.org/licenses/by/4.0/), which permits use, sharing, adaptation, distribution and reproduction in any medium or format, as long as you give appropriate credit to the original author(s) and the source, provide a link to the Creative Commons license and indicate if changes were made.
The images or other third party material in this chapter are included in the chapter's Creative Commons license, unless indicated otherwise in a credit line to the material. If material is not included in the chapter's Creative Commons license and your intended use is not permitted by statutory regulation or exceeds the permitted use, you will need to obtain permission directly from the copyright holder. 